\title{
"FIESTA EDIFICADA, VIVA Y ETERNA": JUSTINO DE NEVE, TORRE FARFÁN Y ALGUNAS CLAVES INTERPRETATIVAS DE SANTA MARÍA LA BLANCA DE SEVILLA
}

\author{
'BUILT-UP, ALIVE AND ETERNAL CELEBRATION': \\ JUSTINO DE NEVE, TORRE FARFÁN AND SOME \\ INTERPRETIVE KEYS OF SANTA MARIA LA \\ BLANCA OF SEVILLE
}

\author{
Álvaro Recio Mir \\ Universidad de Sevilla, España \\ alvarorecio@us.es
}

\begin{abstract}
Desentrañar el significado de la iglesia sevillana de Santa María la Blanca pasa por el análisis de tres cuestiones fundamentales: en primer lugar, la personalidad del canónigo don Justino de Neve, verdadero autor del edificio, así como la coyuntura artística de la Sevilla de hacía 1660-1670. A ello se suma el estudio de las imágenes, emblemas e inscripciones que protagonizan su interior y, por último, el libro que Torre Farfán publicó con motivo de la inauguración del templo, en el que cabe encontrar las pautas fundamentales para entenderlo.

Palabras clave: Santa María la Blanca de Sevilla, Justino de Neve, Fernando de la Torre Farfán, Inmaculada Concepción, fiesta
\end{abstract}

To uncover the meaning of the Sevillian church of Santa Maria la Blanca happens for the analysis of three fundamental questions: first of all, the personality of the canon don Justino de Neve, real artistic author of the building, as well as the artistic conjuncture of the Seville of 1660-1670. To it there adds the study of the images, emblems and inscriptions that lead its interior and, finally, the book that Torre Farfán published on the occasion of the inauguration of the temple, in which it is possible to find the fundamental guidelines to understand it.

Keywords: Santa María la Blanca of Seville, Justino de Neve, Fernando de la Torre Farfán, Inmaculate Conception, celebration

Entendida como paradigma del barroco andaluz, la iglesia sevillana de Santa María la Blanca no reduce su significado al marco artístico local, ya que su conjunto yesero, de "riqueza aturdidora" como señalara Bonet Correa, es el "punto 


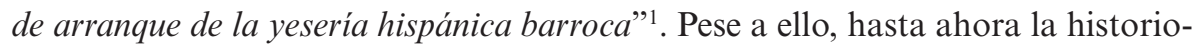
grafía se ha interesado particularmente en la autoría de sus yeserías, sin que aún haya aclarado el alcance que Pedro Roldán pudo tener en su factura ${ }^{2}$. Realmente, es mucho lo que todavía resta saber de este edificio, que, sólo gracias a la iniciativa privada, liderada por su actual párroco, don Manuel Mateo Fraile, digno sucesor de aquel don Domingo Velázquez Soriano que colaboró en su reconstrucción barroca, ha salido de la situación de ruina que amenazaba su propia existencia hasta fechas recientísimas ${ }^{3}$.

Tal acontecimiento es motivo suficiente para analizar de nuevo el edificio y abordar en esta ocasión, más que nuevos datos sobre su construcción, algunas pautas interpretativas que permitan comprenderlo, ya que tras la fascinante configuración de su exaltada ornamentación palpita una realidad intelectual mucho más interesante y viva que los fríos datos documentales y también más difícil de aquilatar ${ }^{4}$.

Sobre tres pilares creemos que pivota la interpretación de todo ello: en primer lugar, sobre la personalidad del canónigo don Justino de Neve, verdadero autor de Santa María la Blanca, así como sobre el medio artístico de la Sevilla del tercer cuarto del siglo XVII; lógicamente, sobre las imágenes e inscripciones que forman su ciclo icónico y, por último, sobre el libro que Torre Farfán publicó sobre este templo, el primero y más interesante que pueda escribirse sobre él y que es fuente esencial para entenderlo.

\section{JUSTINO DE NEVE Y LA COYUNTURA ARTÍSTICA SEVILLANA DE HACIA 1660-1670}

El conocido retrato que de Neve pintó Murillo lo muestra, a pesar de haber cumplido ya los cuarenta, en el ápice de una espléndida plenitud física, así

${ }^{1}$ BONET CORREA, Antonio: Andalucía barroca. Arquitectura y urbanismo. Barcelona, 1978, p. 42.

${ }^{2}$ Roda Peña, el último en ocuparse de ello, apunta una posible colaboración de Roldán y Pedro de Borja, véase RODA PEÑA, José: Pedro Roldán escultor 1624-1699. Madrid, 2012, pp. 313-316.

${ }^{3}$ La restauración la dirigió el arquitecto Óscar Gil Delgado, al que agradecemos su amabilidad, igual que al restaurador Carlos Núñez, así como a Alfonso Pleguezuelo por animarnos a escribir este texto.

${ }^{4}$ Los datos conocidos sobre la reconstrucción barroca del templo han sido recogidos por última vez en FALCÓN MÁRQUEZ, Teodoro: "La iglesia de Santa María la Blanca de Sevilla, punto de encuentro entre Murillo y Justino de Neve" en FINALDI, Gabriele (ed.): Murillo y Justino de Neve. El arte de la amistad. Madrid-Sevilla-Londres, 2012, pp. 61-71. A las interesantísimas conclusiones que ha llegado al respecto Oscar Gil Delgado, aludiremos más adelante. 
como elegante y decidido, culto y devoto ${ }^{5}$. Es sabido que acumuló en vida, además de una cuantiosa fortuna, cualidades personales envidiables. En la Sevilla del siglo XVII era conocido por su devoción, elocuencia, cultura, honradez y afabilidad. Pero junto a estas prendas, cabe destacar ahora su capacidad para la gestión artística.

Así, Santa María la Blanca debe ser entendida como obra de Neve. Sin duda, él dirigió su reconstrucción barroca y la sufragó en parte. El 19 de junio de 1662 informó al Cabildo catedralicio "que los parroquianos de Santa María la Blanca quieren labrar los techos de dicha iglesia de bóvedas de yeso a su costa", prueba de que supo canalizar los afanes artísticos de sus fieles. El Cabildo, a su vez, "estimó el mucho zelo con que el dicho don Justino ha adornado y cuidado desta capilla y dio licencia para que se haga la dicha obra como pareciese al dicho señor canónigo". Pero esta delegación capitular no supuso que la institución se desentendiese del seguimiento de la obra, ya que sólo dos días más tarde acordó ver el "dinero que ay junto para ella y si abrá bastante, no sea que falte después de averse empezado y el Cabildo mandó que en esto no aya novedad sino que el señor canónigo don Justino de Neve cuide de esta obra como le pareciere más conveniente". Sólo tres años después, en mayo de 1665, Neve anunció al Cabildo la conclusión del templo, por lo que la institución "le dio muchas gracias por el gran celo y cuidado que a tenido en la obra de este templo, pues mediante su actividad se a conseguido la perfección della sin que al Cabildo le aya costado un maravedi".

Pero don Justino no sólo se ocupó de su construcción material, también lo hizo de la espiritual, impulsando la hermandad de sacerdotes de la Cátedra de San Pedro que residía en ella. En todo ello tuvo que ver su nombramiento como presidente de capillas del Cabildo, en el que recaía el cuidado de sus iglesias filiales -como era la que ahora nos ocupa-, y en 1667 como mayordomo de fábrica. En este marco le encargó a Murillo la Inmaculada que preside la sala capitular catedralicia y dispuso que hubiese otra en la custodia de Arfe, cuya remodelación, paralela a la de Santa María la Blanca, también auspició él. Esta devoción a la Inmaculada la heredó de su padre, que había dotado una capilla de tal advocación en el convento de San Francisco. Otra prueba de ello fue su participación en

\footnotetext{
${ }^{5}$ Véase la ficha de Finaldi en FINALDI, Gabriele (ed.): Murillo y Justino de Neve... op. cit., pp. 96-98.

${ }^{6}$ Véanse CHERRY, Peter: "Justino de Neve: su vida y obras" y FALCÓN, Teodoro: "La iglesia de Santa María la Blanca..." op. cit., ambos en FINALDI, Gabriele (ed.): $M u$ rillo y Justino de Neve... op. cit., pp. 31 y ss. y 61 y ss.; FALCÓN, Teodoro: "El canónigo Justino de Neve y la iglesia de Santa María la Blanca de Sevilla", Laboratorio de arte, 23, 2011, pp. 589-598 y RECIO MIR, Álvaro: "Mecenazgo capitular y plenitud barroca: Bernardo Simón de Pineda en la catedral de Sevilla". Goya, 350, 2013, pp. 30 y 31.
} 
el pleito que el Cabildo entabló contra José de Velasco, prior de los carmelitas de Sevilla, quien puso en duda tal creencia, por lo que fue excomulgado ${ }^{7}$.

Su testamento está salpicado de pruebas de amor a la Inmaculada, igual que su inventario post mortem de bienes ${ }^{8}$. No obstante, quizá la faceta más brillante de Neve, junto a su mecenazgo, fuese la de orquestar celebraciones religiosas, siendo obra suya dos de las más significativas de la Sevilla barroca: la inauguración de Santa María la Blanca en 1665 y la canonización de San Fernando en $1671^{9}$.

Volviendo a Santa María la Blanca, cabe suponer que su programa iconográfico sea obra suya. Navarrete ha planteado al respecto que su retrato pintado por Murillo pudiera guardar relación con tal programa ${ }^{10}$. Además, todo apunta a que Neve aparece en el lienzo de la Inmaculada del luneto que presidía la nave del Evangelio del templo, lo que certificaría su protagonismo al respecto. Sin duda, Santa María la Blanca es indisociable de Neve, que la debió de entender como algo personal. En tal sentido, a lo anterior hay que sumar que fuese el lienzo de la Inmaculada de su colección el que presidiese el retablo efímero levantado para la inauguración del templo ${ }^{11}$. (Figura 1)

No obstante, ya apuntó Angulo la significación que pudo tener en ello el párroco del templo, don Domingo Velázquez Soriano. Torre Farfán dijo que Murillo lo retrató en el referido cuadro de la Inmaculada de la iglesia y que era "varón de integridad eclesiástica, docto en letras espirituales y de exemplar modestia", añadiendo que tal retrato recordaba "lo que en este edificio se le debe". Por ello Angulo lo llamó "alma de la obra de la iglesia", resaltando su amistad con Neve, al que nombró albacea ${ }^{12}$.

Sin duda, Velázquez Soriano quedó ensombrecido por la brillantez de Neve, cada vez más valorado por la historiografía. La escasez de fuentes sobre este modesto párroco impide profundizar en su personalidad y saber su aportación cierta a la iglesia. De lo que no cabe duda es de que sería un importante colaborador de Neve, como prueban los referidos testimonios de Torre Farfán y Murillo.

${ }^{7}$ CHERRY, Peter: "Justino de Neve...” op. cit., pp. 31-45.

${ }^{8}$ CHERRY, Peter: "Apéndice documental sobre Justino de Neve", en FINALDI, Gabriele (ed.): Murillo y Justino de Neve... op. cit., pp. 143-167.

${ }^{9}$ A la de Santa María la Blanca nos referiremos más adelante, sobre la de San Fernando remitimos a TORRE FARFÁN, Fernando de la: Fiestas de la santa iglesia metropolitana y patriarcal de Sevilla al nuevo culto del señor rey San Fernando... Sevilla, 1671.

${ }^{10}$ NAVARRETE PRIETO, Benito: "Murillo, Neve y los Venerables", en FINALDI, Gabriele (ed.): Murillo y Justino de Neve... op. cit., p. 76.

${ }^{11}$ Sobre ambos cuadros véanse las fichas que le dedican Gabriele Finaldi y Elena Cenalmor Bruquetas en FINALDI, Gabriele (ed.): Murillo y Justino de Neve... op. cit., pp. 110-113 y 114-117 respectivamente.

12 ANGULO ÍNIIGUEZ, Diego: "Las pinturas de Murillo, de Santa María la Blanca", Archivo español de arte, $\mathrm{n}^{\circ}$ 165, 1969, pp. 13-42, en concreto 28 y 29. 
En cualquier caso, la cabal interpretación de la reforma de Santa María la Blanca pasa, además de por fijar nuestra atención en Neve y en Velázquez Soriano, por atender el marco histórico de vibrante exaltación devota que vivía entonces la ciudad y que ha analizado Gómez Piñol en relación a la reconstrucción de la colegiata del Salvador, iglesia con la que tantos paralelismos tuvo Santa María la Blanca, alguno de los cuales veremos más adelante. El referido historiador cifra un crítico marco cronológico entre 1649, año de la epidemia de peste que esquilmó la ciudad, y 1679, cuando fueron prohibidas las representaciones teatrales. Entre tales fechas se produjeron una serie de circunstancias que se entrelazaron en un complejo fenómeno de sinergia histórica con importantes repercusiones artísticas. De tales causas cabe referir, en primer lugar, una exacerbada sensibilidad hacia el decoro en los lugares de culto. A ello se sumó una intensificación del culto a las imágenes, expuestas en aparatosos retablos que "avivaban ancestrales signos de inalienable identidad doctrinal" radicalmente contrarios a los derroteros anicónicos o abiertamente iconoclastas de protestantes y musulmanes ${ }^{13}$.

A ello suma Gómez Piñol la conciencia de un cambio en el gusto artístico y que se materializó en la intensificación del ornamento de los templos. Precisamente fue Torre Farfán el que señaló que la conclusión del Sagrario de la catedral, la construcción de la iglesia de la Caridad y la renovación de Santa María la Blanca rivalizaron en una "emulación piadosa", que él justificaba en la consecución de templos cada vez más suntuosos y acordes con los inflamados sentimientos devotos de la Sevilla de los años sesenta del XVII. Gómez Piñol destaca en tal sentido las yeserías de Santa María la Blanca, que sumadas a los mármoles y pinturas murales de la misma constituyen una síntesis de "ofuscadora y envolvente calidad sensorial". Estas yeserías las interpreta como plasmación de lo que la Sevilla de la época entendió como "forma nueva" de adornar los templos ${ }^{14}$. Este afán de novedad también se evidenció en Santa María la Banca, como prueba el título del libro de Torre Farfán sobre ella, donde especificó que lo escribió "con la circunstancia de averse fabricado de nuevo su templo para esta fiesta", detalle que vincula su arquitectura a la novedad y a tal celebración.

En efecto, el crescendo decorativo de la forma nueva de hacer los templos, cuyos grandes hitos fueron la referida conclusión del Sagrario, la renovación de Santa María la Blanca y la ejecución de la iglesia de la Caridad, culminó

${ }^{13}$ GÓMEZ PIÑOL, Emilio: La iglesia colegial del Salvador. Arte y sociedad en Sevilla (siglos XIII al XIX). Sevilla, 2000, pp. 105-107.

${ }^{14}$ GÓMEZ PIÑOL, Emilio: La iglesia colegial del Salvador... op. cit., pp. 107 y 108. Véase también del mismo autor "La "forma nueva" de adornar los templos sevillanos del siglo XVII y la emulación piadosa. El retablo mayor del hospital de la Caridad", en SÁNCHEZ-MESA MARTÍNEZ, Domingo y LÓPEZ-GUADALUPE MUÑOZ, Juan José (eds.): Diálogos de arte. Homenaje al profesor Domingo Sánchez-Mesa Martín. Granada, 2014, pp. 223-246, particularmente de la 226 a la 228. 
precisamente en una fiesta: la celebración por la canonización de San Fernando en 1671, cuyo triunfo levantado en la catedral exaltaba su santidad a través de la lucha contra el Islam. Tal marco de extremo rigor moral y ostentosa reafirmación religiosa fue atizado, entre otros, por personajes como don Miguel de Mañara o el arzobispo don Ambrosio de Spínola, en última instancia el gran animador de tal renovación estética-espiritual ${ }^{15}$.

Sin duda, la fiesta por la inauguración de Santa María la Blanca fue antecedente esencial de la celebración de la canonización de San Fernando y su reconstrucción modelo de otros eslabones de esa larga cadena que configura la referida forma nueva de hacer los templos, como el oratorio del palacio Arzobispal, las capillas de los Jácome y de San Isidoro en la catedral, el álbum de dibujos D.Z., la capilla sacramental de San Esteban o el templo del convento de los Terceros ${ }^{16}$.

Cabe insistir en los paralelismos entre Santa María la Blanca y el Salvador, este último edificado debido a lo insoportable que resultaba, en la coyuntura referida, rendir culto a Dios en una desvencijada y hundida mezquita, por ello el nuevo Salvador se levantó sobre una plataforma de tal altura que requería de una escalinata para su acceso ${ }^{17}$. Por su parte, Santa María la Blanca sumaba a su pasado musulmán la lacra judía, por lo que su renovación estaría motivada, junto al breve de Alejandro VII a favor de la Inmaculada, por la intención de hacer desaparecer toda referencia a esas religiones malditas en la Sevilla del siglo XVII. Es más, en la reconstrucción del edificio, en la que se reutilizaron buena parte de las estructuras de su vieja fábrica, se aprovechó para darle una vara más de altura ${ }^{18}$, en significativo paralelo a lo sucedido en el Salvador.

Este marco local cabría incluirlo en el más general señalado por Maravall para la cultura del barroco. El referido historiador entiende el barroco como fundado, más que en aspectos externos e instrumentales, en una cultura dirigida, masiva, urbana y conservadora. En tal sentido, hace hincapié en los recursos psicológicos empleados por el barroco para atraer, retener y conducir la atención de la sociedad. El primero de ellos fue la extremosidad, entendida como un alegato a la exageración y a lo desmesurado, con la finalidad de golpear el ánimo de las

${ }^{15}$ GÓMEZ PIÑOL, Emilio: La iglesia colegial del Salvador... op. cit., p.108 y ss.

16 Véase RECIO MIR, Álvaro: "Génesis del ornato barroco sevillano: causas y significación”, en Barroco Iberoamericano. Territorio, arte, espacio y sociedad, Sevilla, 2001, vol. $2^{\circ}$, pp. 941-961.

${ }^{17}$ Imprescindible al respecto es GÓMEZ PIÑOL, Emilio: La iglesia colegial del Salvador... op. cit.

${ }^{18}$ Véanse los interesantes trabajos GIL DELGADO, Óscar: "Una sinagoga desvelada en Sevilla: estudio arquitectónico", Sefarad, 73.1, 2013, pp. 69-96 y, del mismo autor, "Santa María la Blanca de Sevilla, templo de tres religiones. Estudio arquitectónico", Archivo hispalense, 291-293, 2013, pp. 65-97. Véase también CÓMEZ, Rafael: Sinagogas de Sevilla. Sevilla, 2015, pp. 109-123 
personas para que quedasen espantadas y asombradas. A ello sigue el recurso de la suspensión, efecto que provoca una situación de suspense. También alude al recurso de la dificultad, en relación al cual cita Maravall a Gracián que decía que "a más dificultad más fruición del discurso en topar con el significado". Un nuevo recurso era la novedad, es decir, la rareza o la ruptura de las normas. Por último, trata de la invención y el artificio, desarrollados en el teatro del Siglo de Oro. Maravall señala que estos recursos fueron empleados porque el hombre barroco no tuvo demasiada confianza en la fuerza de atracción de lo intelectual ${ }^{19}$.

Santa María la Blanca fue paradigma de esta forma nueva de hacer los templos barrocos, ya que en ella se desarrollaron los recursos referidos e incluso otros que más adelante veremos y que aún siguen impactando a quien entra en tan oclusivo espacio.

\section{ALGUNAS CONSIDERACIONES SOBRE LAS IMÁGENES, LOS EMBLEMAS Y LAS INSCRIPCIONES}

Debido a que las pinturas de Santa María la Blanca son de Murillo han sido muy estudiadas. Menos sabemos de la titular del templo, la Virgen de las Nieves, y tampoco mucho sobre las imágenes insertas en las yeserías de sus bóvedas, ni sobre las inscripciones que tapizan su interior. Algunas de éstas han desaparecido o están ocultas por retablos posteriores, lo que complica plantear cual fue el ciclo icónico original. Además, tras la reforma barroca parte de las imágenes del viejo edificio pasarían al nuevo. Con tales premisas, más que reconstruir el primitivo programa iconográfico de la Santa María la Blanca barroca, ofreceremos algunas consideraciones al respecto.

Cabe partir de que no sabemos cuál era la iconografía del templo precedente, aunque lo presidía la Virgen de las Nieves igual que hoy. Falcón ha reunido varios datos sobre esta imagen, al parecer una talla del siglo XVI que aparecía sobre un monte nevado, en alusión al Esquilino. Supone dicho autor que con la remodelación del templo en el siglo XVII, la imagen fue transformada para poder ser vestida con telas reales. Pese a ello mantuvo su iconografía al conservar el monte a sus pies, como muestra la estampa de Matías de Arteaga que abre el libro de Torre Farfán. Tras ello fue de nuevo transformada y, pese a que la actual se ha atribuido a Juan de Astorga, parece ser una obra anónima de 1864 sin referencia alguna al monte nevado ${ }^{20}$. (Figura 2)

${ }^{19}$ MARAVALL, José Antonio: La cultura del barroco. Análisis de una estructura histórica. Barcelona, 1986, pp. 419-524.

${ }^{20}$ FALCÓN MÁRQUEZ, Teodoro: "Retablos y esculturas de la iglesia de Santa María la Blanca de Sevilla". Laboratorio de arte, ${ }^{\circ} 25,2013$, vol. $1^{\circ}$, pp. 303-307. Sin duda esta imagen y su iconografía merecerían un estudio pormenorizado. Hay que tener en cuenta, que a pesar de lo antes dicho, la Virgen debía de haber perdido ya en 1665 su referencia al Esquilino, ya que si no no se entiende la descripción que tenemos de la misma en 
Quizá la renovación de la imagen que recoge Matías de Arteaga pudiera extender su devoción y tuviera que ver con que en 1666, sólo meses después del estreno del templo sevillano, fuese demolida la capilla mayor de la colegiata de Olivares, dedicada también a las Nieves, para construir una mejor. Sabemos que el retablo que presidía la vieja capilla mayor contaba con los mismos asuntos que pintó Murillo para la iglesia sevillana ${ }^{21}$, por lo que es posible la influencia entre ambos templos.

En cualquier caso, la Virgen de las Nieves de Santa María la Blanca fue vinculada con insistencia con la Inmaculada Concepción en el libro de Torre Farfán, donde son numerosas las referencias a esta imagen como "Blanquísima Señora" o "pura, limpia y blanca, aún más que los albores de la Nieve". La misma fuente permite que sepamos quién promovió esta identificación, ya que al aludir al cuadro de la Inmaculada que presidió el retablo efímero que se alzó para la inauguración dice que se pintó "a devoción de un esclavo de la Virgen", en clara alusión a Neve, que no es citado en toda la obra, lo que prueba que fue él quien la ideó, promovió y llenó de contenido ${ }^{22}$.

La vinculación de las Nieves y la Inmaculada se ve también en las pinturas de Murillo, tanto en los medios puntos que flanqueaban la cúpula, como en la Inmaculada de la nave del Evangelio, venerada, entre otros, por $\mathrm{Neve}^{23}$.

Aunque sólo sean conjeturas ¿acaso no podría hacer referencia la blancura de las yeserías a la nieve que derramó la Virgen en el Esquilino?, ¿sería posible que el fondo dorado de las mismas aludiera a la Inmaculada Concepción en referencia a la mujer vestida de Sol que refiere el Apocalipsis? En cualquier caso, donde la asociación de la Inmaculada a las Nieves resultó más evidente fue en las fiestas por el estreno del templo, presididas por el referido retablo efímero de la Inmaculada. En el interior del templo, mientras, los retablos estuvieron revestidos de

la procesión con la que culminó la inauguración del templo. Véase, además del imprescindible Torre Farfán, SERRANO Y ORTEGA, Manuel: Glorias sevillanas. Noticia histórica de la devoción y culto que la muy noble y muy leal ciudad de Sevilla ha profesado a la Inmaculada Concepción de la Virgen María. Sevilla, 1894, p. 546.

${ }^{21}$ Véase AMORES MARTÍNEZ, Francisco: La colegiata de Olivares. Sevilla, 2001, pp. 38 y 39 .

${ }^{22}$ Las citas las tomamos de TORRE FARFÁN, Fernando de la: Fiestas que celebró la iglesia parroquial de Santa María la Blanca, capilla de la Santa Iglesia metropolitana y patriarchal de Sevilla en obsequio del nuevo breve concedido por nuestro santísimo padre Alejandro VII a favor del puríssimo mysterio de la concepción sin culpa original de María Santísima Nuestra Señora en el primero instante phísyco de su ser con la circunstancia de averse fabricado de nuevo su templo para esta fiesta. Sevilla, 1666, tercera aprobación, sin foliar, y fol. 7. Citamos por el ejemplar del fondo antiguo de la Biblioteca General de la Universidad de Sevilla, A 088/106, disponible en la red.

${ }^{23}$ Véanse las fichas que se les dedican en FINALDI, Gabriele (ed.): Murillo y Justino de Neve... op. cit. 
azul, en alusión a la Inmaculada ${ }^{24}$. El retablo efímero pudiera entenderse como una suerte de contestación al que presidía la iglesia y el revestimiento de los otros como su "inmaculización".

Por lo que se refiere a las inscripciones del templo, la primera está en la fachada y aunque es posterior a la transformación de 1665 no deja de ser una clave general para la interpretación del conjunto: "Haec est Dominus Dei et porta coeli 1741 ”. Tomada del Génesis 28, 17, en relación al sueño de Jacob, al que se hará referencia en el interior, en el que vio una escalera que daba acceso "a la casa de Dios y a la puerta del cielo".

Bajo el coro dos filacterias proclaman "Sin pecado original en el primer instante de su ser", mientras la bóveda del sotocoro la preside un renovado anagrama mariano rodeado de flores y frutas. Se da la circunstancia de que el marco de la Inmaculada de la sala capitular catedralicia, encargo también de Neve, tiene una inscripción casi idéntica, que cabe entender como declaración de intenciones de todo el ciclo. (Figura 3)

Si leemos el resto de las inscripciones desde la nave del Evangelio a la de la Epístola, vemos en primer lugar, presidiendo los pies de la del Evangelio, un texto casi borrado que dice "Veni ostendam tibi spons xorema. Apocalip. 21". Es el versículo 9 de dicho capítulo apocalíptico, en el que San Juan narra que uno de los siete ángeles se acercó y le dijo "ven que te voy a mostrar la esposa del cordero". Lo que le mostró fue la Jerusalén celeste, que bajaba del cielo junto a Dios y de la que dice que su esplendor era como el de una piedra preciosísima y el jaspe cristalino. Cabe entender tal inscripción como encabezamiento del ciclo, en clara referencia a la Virgen. (Figura 4)

A continuación, en el muro Norte, otra inscripción dice "Oliba speciosa incampis, Eclesiast, 24", tomada del Eclesiástico, uno de los Libros Deuterocanónicos, en cuyo capítulo 24 se alaba la sabiduría, vinculada a Jesucristo, de la que se dice que creció como cedro del Líbano, ciprés de la montaña de Hermón, palmera de Engadí, rosal de Jericó o, en el versículo 14, como un "olivo hermoso en la llanura", que vemos pintado en el correspondiente emblema, ubicado entre esta inscripción y la anterior.

Tras la anterior hay dos inscripciones superpuestas y perdidas, aunque también dedicadas a la Virgen, ya que en una de ellas aun puede leerse "regina" 25. La siguiente inscripción, también sobre ese muro Norte, dice en su parte superior "Stela matutina in medio nebulae. Eclesiast, 50", capítulo del Eclesiástico que trata del sumo sacerdote Simón, que restauró el Santuario de Jerusalén y del que

${ }^{24}$ Sobre estas fiestas véanse SERRANO Y ORTEGA, Manuel: Glorias sevillanas...

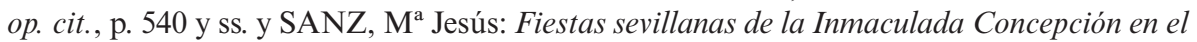
siglo XVII. El sentido de la celebración y su repercusión exterior. Sevilla, 2008, p. 180 y ss.

${ }^{25}$ Esperamos que una próxima restauración solucione esta y otras dudas de este ciclo iconográfico. 
se dice que era como "estrella de la mañana en medio de nubes". Junto a ello se ve el correspondiente emblema de la estrella pintada, aunque casi borrado, tomada de las Letanías Lauretanas.

La inscripción que aparece bajo la anterior dice "Ipsa vero civitas aurum mundum simile vitro mundo, Apocalip. 21". Relativa a la Jerusalén celeste, de la que señala que bajaba del cielo al lado de Dios, como una esposa ataviada para su esposo y que es descrita como "la ciudad es de oro puro, semejante al puro cristal".

"Gloriosa sunt dicta de te, civitas Dei, Psalm 86", dice la siguiente cartela cuyo texto es tomado del himno a Sión del Libro de los Salmos, que señala en el número referido que Dios fundó Sión sobre los montes santos y que Dios ama a Sión. A ello se suma la frase "Que cosas tan hermosas se pregonan de ti, ciudad de Dios".

Frente a las anteriores, están las inscripciones que se disponen sobre los arcos que separan esa nave con la central. La primera alude a "Arcam Dni Domini Israel, $1^{\circ}$ lib, paralip, 15 ". Dicho capítulo de lo que hoy llamamos Libro primero de las crónicas narra que David reunió a todos los pueblos de Israel para que trasladasen el Arca de la Alianza y el versículo 14 indica que los sacerdotes y levitas se purificaron para llevar "el arca del Señor, Dios de Israel", lo que hace de nuevo alusión a la Virgen. Junto al texto una cartela recoge un emblema alusivo, es decir, un barco.

Sobre el siguiente arco leemos "Lilivm inter spinas. Cant. 2". Capítulo del Cantar de los Cantares en el que Dios dice que Él es narciso de Sarón, lirio de los valles y que su amada es como "lirio entre cardos", junto a lo cual aparece pintado el correspondiente emblema en una cartela.

La siguiente inscripción es "Navi sin medio mari, Proberb.30", capítulo del Libro de los Proverbios que recomienda no añadir nada a la palabra de Dios y que alude al sendero del águila en los cielos, de la serpiente en la tierra o "de la nave en el mar". El correspondiente emblema refleja una imagen de una nueva embarcación.

Sobre el siguiente arco vemos "Pvlchra vt lvna, Cant. 6", capítulo del Cantar de los Cantares en el que el amado dice de la amada que es "bella como la luna". Le sigue el texto "Electa vt sol. Cant. 6", continuación del anterior y que alude a la amada como "distinguida como el sol". Tanto el sol como la luna aparecen en sendos emblemas.

La última inscripción de la nave del Evangelio dice "Cypresvs in monte Sion. Eclesiast. 24", capítulo del Eclesiástico que elogia la sabiduría, que creció como cedro del Líbano y "como un ciprés en el monte Sión".

Sobre las anteriores inscripciones, en la parte alta de los muros que configuran la nave se suceden giraldas y jarros de azucenas, escudo del Cabildo de la catedral, institución a la que pertenecía Santa María la Blanca. (Figura 5)

En la nave de la Epístola, sobre los arcos que la separan de la central, leemos en primer lugar "Templvm Spiritv Sancti. 1 Corinth 6". El versículo 18 de tal capítulo de la Primera carta a los corintios invita a rechazar la lujuria ya que en el siguiente versículo se formula la pregunta: ¿no sabéis que vuestro cuerpo es "templo 
del Espíritu Santo?'. Este texto está acompañado por un emblema que muestra una iglesia coronada por el Espíritu Santo y que alude de nuevo a las Letanías Lauretanas.

A continuación vemos "Porta Caeli, Genesis 28", en referencia al sueño de Jacob. Una vez que despertó de él dijo que Dios estaba allí y que él lo sabía, por lo cual sintió miedo y afirmó, en el versículo 17 de dicho capítulo, que esa era la casa de Dios y la "puerta del cielo", que vemos en el emblema. Esta frase, relacionada con la de la fachada de la iglesia, vuelve a vincular este ciclo con las Letanías Lauretanas.

El siguiente texto dice "Scala Iacob. Genesis. 28". En el sueño de Jacob el Señor le anunció que por su descendencia sería bendecida por todas las naciones de la tierra y que no le abandonaría. También vemos un emblema con la referida escalera.

Una nueva inscripción dice "Fons patents domvi iacob, Zachar. 13", capítulo de Zacarías que alude a la fuente purificadora de los pecados y que empieza diciendo que brotará un manantial para la casa de David y los habitantes de Jerusalén, el cual lavará los pecados. Un emblema con una fuente alude a la referida en el texto.

"Hortvs conclvsvs. Cantic. 4" es el siguiente texto, tomado del referido capítulo del Cantar de los Cantares en el que el amado hace una descripción ensalzando a su amada, en concreto, en el versículo 12 dice: "jardín cerrado eres hermana mía, novia mía, un manantial cerrado, una fuente sellada”. Este huerto cerrado es representado en el correspondiente emblema, una vez más en relación con las Letanías Lauretanas.

Por último, una inscripción del capítulo 24 del Eclesiastés remata esta arquería: "Plantatio rosae in Hierico. Eccti. 24", elogio de la sabiduría que creció como cedro del Líbano, ciprés del monte Sión y "los rosales de Jericó”, que también aparecen en un emblema, que de nuevo es una alusión a la Virgen.

Sobre estos arcos que separan la nave de la Epístola de la central y sobre las inscripciones que veremos en adelante volvemos a encontrar las pinturas de giraldas y jarros de azucenas en alusión al escudo del Cabildo.

En el muro sur del edificio leemos, "Platanvs exaltata, Ecclesiasti. 24", que repite la fuente del Eclesiástico, en relación a la sabiduría de la que se dice, además de que creció como cedro del Líbano y ciprés de Sión, "como un plátano me elevé".

A continuación encontramos "Lilivm distillans myrrham. Cant. 5", tomada de ese capítulo del Cantar de los Cantares, versículo 13. Es una descripción que hace la amada de su amor, del que señala que es rubio y radiante, sus cabellos de oro, sus ojos como palomas o que sus labios son "lirios que destilan mirra".

Le sigue una inscripción doble, que en su parte alta dice "Specvlvm sine macvla. Psalm.7", que pese a señalar que está tomado del libro de los Salmos lo está del de la Sabiduría, 7, 26, donde Salomón alude a que la sabiduría procede de Dios, ya que es resplandor de la luz eterna y "espejo inmaculado" de la actividad divina. También en esta ocasión se conserva el emblema con el correspondiente espejo, tomado de 
las Letanías Lauretanas. Bajo ello leemos: "Opera dni qvae posvit prodigia super terram. Psalm. 45", inscrito en dicho salmo que canta las "obras del Señor y sus prodigios que llenan la tierra de estupor", en alusión a la Inmaculada.

Una nueva inscripción doble dice en su parte superior "Tvrris David cvm propuq nacvlis. Cant. 4", también referida a la descripción que realiza el amado de la amada, de la que dice "como torre de David es tu cuello", edificado como fortaleza. Una torre es el emblema que acompaña a la inscripción tomada de las Letanías. (Figuras 6 y 7)

Bajo la anterior se lee "Fecit mihi magna potens est. Lvcae 1", tomado del versículo 49, que narra la Visitación, cuando María dijo que Dios "ha hecho conmigo cosas grades", por eso las generaciones la llamaron dichosa.

El siguiente texto dice en la parte superior "Vrna aurea habens manna. Hebr. 9", capítulo de la Carta a los hebreos que describe el primitivo tabernáculo, en cuyo interior estaba el Arca de la Alianza, la cual, a su vez, contenía un "vaso de oro llenó de maná", la vara de Aarón y las Tablas de la Ley, como señala el versículo cuarto de tal capítulo. También en este caso se conserva el emblema con la referida jarra.

Bajo el anterior texto leemos "Astitit Regina a dextrist visin vestitu del aurato. Psalm. 44", tomado del poema nupcial al rey mesiánico que protagoniza tal capítulo del Libro de los salmos, en el que se dice que entre las hijas de todos los reyes hay una "reina engalanada con tejidos de oro", una vez más en referencia a la Virgen.

A los pies de esta nave de la Epístola vemos las dos últimas inscripciones, que tienen más relación con la capilla bautismal en la que están que con el conjunto. La primera, sobre el arco de acceso a la capilla, es "Mathei, cap. 3. Hic est filivs mevs dilectvs, in qvo mihi complacvi", en referencia al bautismo de Jesús. El versículo 16 de tal capítulo dice que tras su bautismo se abrió el cielo, el Espíritu de Dios descendió en forma de paloma y se posó sobre él y que una voz dijo "este es mi hijo amado, mi predilecto". Dentro de la capilla otra inscripción dice "Nisiqvis renatvs fveritex aqva\& spiritv sancto non potest introire in regnvm Dei. Joanes, cap. 3". Es la conversación de Nicodemo y el Señor en la que le dijo que si no nacía de nuevo no podía ver el reino de Dios. Nicodemo le preguntó si se podía nacer de nuevo, a lo que Jesús contestó: "el que no nace del agua y del Espíritu no puede entrar en el reino de Dios".

Aunque nunca se han analizado -ni siquiera han sido recogidas-, Falcón apunta que Murillo debió dirigir la pintura de estas inscripciones. En concreto, señala la posibilidad de que su autor material fuera Alonso Pérez, que años antes de su reforma barroca había realizado algunas pinturas en el templo ${ }^{26}$.

${ }^{26}$ FALCÓN MÁRQUEZ, Teodoro: "La iglesia de Santa María la Blanca de Sevilla, punto de encuentro..." op. cit., p. 61. Estando en prensa este artículo ha aparecido 
En cuanto a su significación, cabría preguntarse si se trata de un conjunto, como parece, que claramente supone un alegato a la Inmaculada Concepción. Destaca que las inscripciones sean en su inmensa mayoría latinas, ya que Torre Farfán, sobre las del retablo efímero de la fiesta por la inauguración del templo, indicó que "no pareció poner motes latinos, aunque la Escriptura ofrece tantos del intento, por no desabrir la ingenuidad de muchos que ignorándolos culpan la providencia clara en misterio donde no quieren nada obscuro" ${ }^{27}$. Por el contrario, en el interior del templo se empleó el latín, quizá porque estas inscripciones eran reconocidas por los fieles, en particular las Letanías, incluso por los iletrados, ya que sus emblemas permitían identificarlas.

Es digno de mención que Torre Farfán también haga referencia a algunos de los emblemas antes referidos. En concreto, estaban en el retablo que presidía la fiesta, el primero de los cuales era un sol, acompañado por una composición poética, al que le sucedían la azucena, el ciprés, la rosa, el lirio, la palma y el espejo. En cualquier caso, los textos e imágenes de la iglesia, más que a la Virgen de las Nieves, están vinculados a la Inmaculada Concepción. Todo ello estaría articulado por Neve, tan devoto de este misterio, como vimos. Nada tiene tampoco de particular en el marco de la Sevilla del siglo XVII, que estaba absolutamente empeñada en su defensa ${ }^{28}$.

Muy llamativas en este conjunto resultan las imágenes de Felipe IV y Mariana de Austria. Ubicadas sobre el coro, él en el lado del Evangelio, ella en la epístola, apenas son visibles, por lo que nadie ha reparado en ellas. No cabe olvidar la enorme significación que en la causa inmaculista tuvo la Monarquía Católica, a la que Felipe III y Felipe IV mostraron apoyo incondicional, como reconoció el breve de Alejandro VII Sollicitudo omnium ecclesiarum del 8 de diciembre de 1661 al señalar: "como casi todos los venerables obispos de las Españas, con los cabildos de sus iglesias, con cartas nos han representado, allándose también la manifestación de deseo del muy amado en Christo, hijo nuestro Felipe, rey católico de las mismas Españas". Insistía en ello al reconocer que la Iglesia celebraría la Concepción Inmaculada de la Virgen a instancias de obispos, cabildos y del "rey Felipe"29. (Figuras 8 y 9)

El mismo año de su acceso al trono, 1621, Felipe IV escribió al papa Gregorio $\mathrm{XV}$ para decirle que de sus antepasados había heredado tal devoción y pedirle

FALCÓN MÁRQUEZ, Teodoro: La iglesia de Santa María la Blanca y su entorno. Arte e historia. Sevilla, 2015, pp. 93-97, donde se recogen algunas de estas inscripciones.

${ }^{27}$ TORRE FARFÁN, Fernando de la: Fiestas que celebró la iglesia parroquial... op. cit., fol. 8 vto.

${ }^{28}$ Véase al respecto SERRANO Y ORTEGA, Manuel: Glorias sevillanas... op. cit.

${ }^{29}$ SANZ, M Mesús: Fiestas sevillanas de la Inmaculada Concepción... op. cit., p. 171. En FALCÓN MÁRQUEZ, Teodoro: La iglesia de Santa María la Blanca... op. cit., p. 29 se relacionan estos bustos con los marqueses de Villamanrique. 
que "trate de ensalzarla y extenderla". El pontífice respondió con la decretal Sanctissimus, que prohibía toda afirmación privada que sostuviera que la Virgen había sido concebida con la mancha del pecado Original. A partir de ese momento la iconografía del rey se asoció a la de la Inmaculada Concepción. Pero el rey no estuvo solo en tal causa, la reina Mariana de Austria, le presionó tanto a él como al papa en defensa de tal creencia, lo que también hizo que su imagen se viese asociada a la de la Inmaculada ${ }^{30}$.

No obstante, la causa inmaculista sufrió un serio revés cuando a Gregorio XV le sucedió en 1623 Urbano VIII, poco proclive a España. No obstante, al iniciarse el pontificado de su sucesor, Inocencio X, la situación cambió. La promulgación de la bula In his per quae estableció que la Inmaculada Concepción fuese fiesta "in Regnis Hispaniarum tantum". Se creyó que España tenía una misión trascendental al respecto y que su suerte estaba unida a la Inmaculada. Significativas resultan las palabras de Sor María Jesús de Agreda, tan próxima a Felipe IV y que le recordó que "a la reina del cielo hemos de poner por intercesora, abogada y restauradora de esta monarquía". Se unía así la suerte de la monarquía y de España a la de la Inmaculada, como cuando la mística afirmaba que "muy poderoso espero ha de ser para todo el asentar la definición del misterio de la Concepción de la Reina del Cielo". Por ello, Felipe IV no cesó en su empeño, logrando grandes victorias, como la proclamación por Alejandro VII del patronazgo de la Virgen sobre España en 1656 y cinco años después la referida bula Sollicitudo omnium ecclesiarum. En 1664 el mismo pontífice concedió a España el derecho de celebrar de precepto el oficio y misa de la Inmaculada, que luego Felipe IV logró que fuese ampliado a Nápoles, Sicilia, Cerdeña, Flandes y Borgoña ${ }^{31}$.

Pero este empeño no sólo era devocional, lo que subyacía bajo ello era el deseo de España de mantener su influencia sobre la Iglesia, sobre esa Roma que Dandelet califica de española. Este autor ha hecho un vivo retrato de la pugna entre España y Francia por la supremacía sobre la Iglesia, en el que ha destacado que, cuando el imperio hispánico parecía que estaba a punto de descomponerse, "una vez más, el mito y la ciudad de Roma proporcionaron a los españoles una historia y un escenario para reflexionar sobre el propio destino como heredera moderna del Imperio Romano". No es de extrañar en ese contexto que cuando supo de la elección de Alejandro VII, Felipe IV le felicitara y le ofreciese su vida y sus reinos por la Iglesia ${ }^{32}$. En ese contexto es en el que hay que entender la remodelación de Santa María la Blanca.

${ }^{30}$ STRATTON, Suzanne: "La Inmaculada Concepción en el arte español”, Cuadernos de arte e iconografía, 2, 2008, pp. 3-128, véanse en concreto las pp. 73-75.

${ }^{31}$ STRATTON, Suzanne: "La Inmaculada Concepción..." op. cit., pp. 79-83.

32 DANDELET, Thomas J.: La Roma española (1500-1700). Barcelona, 2002, pp. 247 y ss. 
La vinculación de Felipe IV no quedó reducida a la Inmaculada, su relación con la Virgen de las Nieves fue tan personal que el atrio de la basílica romana de Santa María la Mayor aún es presidido por una estatua suya. Él fue el primer rey de España nombrado protocanónigo honorario del Cabildo de dicha basílica, lo que proclamó la ancestral generosidad de la Monarquía española con el viejo templo romano, en cuyo interior, por cierto, están representadas las mismas imágenes que en Santa María la Blanca de Sevilla, La Virgen anuncia al patricio Juan el milagro y Juan ante el papa ${ }^{33}$.

En cualquier caso y aunque no vayamos a analizar ahora tal cuestión, no está de más destacar que estas imágenes de yeso de Felipe IV y Mariana de Austria, aunque algo estereotipadas, son ejemplos excepcionales de retratos reales en la escultura sevillana del siglo XVII. La imagen del rey, cabría enlazarla con el retrato de barro que de Felipe IV llevó a cabo Martínez Montañés para la escultura de bronce que Pietro Tacca hizo del monarca. Se da la circunstancia de que en ambos aparece con perilla y golilla. Por su parte, la reina recuerda a los tipos femeninos de Pedro Roldán.

Pero no sólo se homenajeaba al rey al incluirlo en el programa del edificio, también al Cabildo catedralicio, ya que Santa María la Blanca cabe entenderla, al aparecer el escudo capitular reiteradamente, como un monumento a dicha institución. A ello aún habría que añadir otras imágenes que suponemos tendrían significación propia en este complejo entramado. Por ejemplo, los cuatro niños de yeso que ocupan las pechinas de la cúpula, los dos ángeles que sostienen una corona en segura referencia a la Virgen, los platos de comida que abundan entre un mar de rizadas cortezas, igual que flores y frutas y aún las ululantes carátulas que abundan en este universo de yeso. Particular significación por su número han de tener los referidos platos de frutas y verduras, bodegones escultóricos de rara perfección técnica y que quizá cabría entender como dones divinos. Todos estos elementos no eran meramente decorativos, más bien formarían parte de un conjunto iconológico lejos aún de ser desentrañado y que estaba centrado en la Inmaculada Concepción de la Virgen, cuyo misterio lo fundamentaban principalmente textos y emblemas veterotestamentarios como ya vimos. (Figura 10)

\section{TORRE FARFÁN Y LA INTERPRETACIÓN DE SANTA MARÍA LA BLANCA}

Recientemente Portús ha destacado que Torre Farfán es no sólo fuente esencial para conocer el medio artístico sevillano, sino que su obra configura una de las grandes teorías artísticas del siglo de Oro español, una de cuyas principales

\footnotetext{
${ }^{33}$ ANGULO ÍÑIGUEZ, Diego: "Las pinturas de Murillo...”, op. cit., p. 17.
} 
premisas fue la subordinación de la obra a su función devocional, como en el caso que tratamos ${ }^{34}$.

A pesar de ello, la obra del presbítero don Fernando de la Torre Farfán, poeta, dramaturgo y traductor, no está estudiada y parte de ella permanece aún inédita, como una descripción de la custodia de la catedral para la que se hicieron las conocidas estampas de Valdés Leal tras la reforma de la misma. A ello hay que añadir otras obras perdidas, como Laurel de Apolo, que era la introducción a un certamen poético sobre la Inmaculada Concepción celebrado en el Alcázar de Sevilla en $1652^{35}$.

Hay que insistir en la relación de Neve y Torre Farfán. El primero fue albacea y legatario del segundo, llegando a declarar: "me alegrara ser muy poderoso para satisfacer y pagar lo mucho que devo al dicho don Justino" 36 . En concreto, a Neve fueron a parar los papeles de Torre Farfán ${ }^{37}$, lo que prueba su total comunión de ideas.

De los tres grandes libros de Torre Farfán, el del Sagrario de la catedral, de 1663; el de las fiestas de la iglesia de Santa María la Blanca, de 1665 y el de las fiestas por la canonización de San Fernando, de 1671, el que lógicamente más nos interesa ahora es el segundo. No obstante, no fue esta su única vinculación con Santa María la Blanca, de la que además era vecino y hermano de las cofradías allí radicadas ${ }^{38}$.

El título del libro que ahora nos ocupa es en sí mismo significativo: Fiestas que celebró la iglesia parrochial de Santa María la Blanca, capilla de la santa iglesia metropolitana y patriarchal de Sevilla, en obsequio del nuevo breve concedido por nuestro santísimo padre Alexandro VII a favor del puríssimo mysterio de la Concepción sin culpa original de María Santísima Nuestra Señora, en el primer instante physico de su ser con la circunstancia de averse fabricado de nuevo su templo para esta fiesta. A ello hay que sumar un texto que aparece en la portada tras el título: "Dedícase a la augusta Blanquísima señora, por el postrado afecto de un esclavo de su Purísima Concepción" ${ }^{39}$. Sin duda, como ya vimos, ese esclavo era Neve, que no sólo organizó la renovación de la iglesia y la fiesta de inauguración

${ }^{34}$ PORTÚS PÉREZ, Javier: "Los discursos sobre el arte de la pintura en la Sevilla de Justino de Neve", en FINALDI, Gabriele (ed.): Murillo y Justino de Neve... op. cit., p. 47 y ss.

${ }^{35}$ Véanse TORRE FARFÁN, Fernando de la: Poesías. Sevilla, 1915 y REYES, Rogelio: "Fernando de la Torre Farfán: un animador de justas poéticas en la Sevilla del siglo XVII". Dicenda, 6, 1987, pp. 501-507.

${ }^{36}$ CHERRY, Peter: "Apéndice documental...", op. cit., p. 153.

${ }^{37}$ TORRE FARFÁN, Fernando de la: Poesías... op. cit., p. 11.

${ }^{38}$ FALCÓN MÁRQUEZ, Teodoro: "Retablos y esculturas..." op. cit., pp. 305 y 307.

39 TORRE FARFÁN, Fernando de la: Fiestas que celebró la iglesia parrochial... op. cit., sin paginar. 
sino que también debió de encargarse de la edición del libro. Otros detalles en el interior del mismo apuntan en la misma dirección, aunque el nombre de Neve no aparece en el libro, en el que quedaron recogidos los demás integrantes del equipo que dirigió el modesto canónigo, que no quiso quedar registrado en la que seguro fue la gran empresa artística de su vida.

Dos son las cuestiones apuntadas en el título que merecen ser desarrolladas, la exaltación de la Inmaculada y que el edificio se fabricara para esta fiesta, sin duda básicas pasa la interpretación de la obra. El protagonismo de la Inmaculada frente a la Virgen de las Nieves se solucionó asociando una a otra, como apuntamos. Así, Torre Farfán dedica el libro a la "reyna de los Ángeles, María, señora nuestra, concebida sin mancha de original culpa". A ello suma que la Inmaculada fue la gran devoción de "nuestro monarca Felipe Quarto (que está en gloria)", que ya vimos en sus yeserías ${ }^{40}$.

El grueso del libro hace relación a las fiestas por el referido breve pontificio y a la inauguración del templo. En todo ello se vislumbra la figura de Neve, nunca mencionado, como cuando se alude al cuadro de la Inmaculada de Murillo que centraba el retablo efímero que presidía la fiesta, del que dice que se pintó, como vimos, "a devoción de un esclavo de la Virgen". Torre Farfán alude al marco de tal pintura, con la misma simbología de la iglesia, especificando que tal marco tenía "entallados los atributos con que se simboliza la pureza de tan soberana señora"

Otro detalle de la fiesta que permite entender la iglesia son las inscripciones del retablo efímero que la presidía, que Farfán redactó en castellano. Más paralelismos entre la fiesta y la iglesia eran los emblemas del sol, las azucenas, las rosas, los lirios, la palma o el espejo. Como ejemplo de estas inscripciones, traeremos a colación la de las azucenas: "de mi pureza tomaron/ por luzir de gracia llenas/ lo blanco las açucenas" ${ }^{42}$.

La relación de la fiesta alude lógicamente a la iglesia, como cuando, durante la celebración, se abrieron sus puertas: "entonces se abrió aquel Alcáçar de María, aquella puerta del cielo de sus devotos, aquel asilo de todos los necesitados"43.

Junto a esa pauta interpretativa general, podemos añadir muchas otras. Por ejemplo, el primer día de la novena que sucedió a la apertura del templo, el predicador, Pedro Francisco Levanto, arcediano de Reina y capellán real, aludió al primitivo como "un templo pequeño, deslucido y que tanto amenaza ruina" por lo que "hase de fortalecer, renovar y hermosear este templo de suerte que en él se celebre con lucimiento el breve". No obstante, lo más significativo es que dijo que el nuevo templo "no sólo sea teatro de la fiesta, sino la misma fiesta nuestra, edificada, permanente, pyrámide famosa que erija esta parrochia ilustre para que perpetuamente

\footnotetext{
${ }^{40}$ Ibídem, sin paginar.

${ }^{41}$ Ibid., fol. 7 vto.

${ }^{42}$ Ibíd., fols. 8 vto.-12.

${ }^{43}$ Ibíd., fol. 16.
} 
esté celebrando la gracia del primer instante de la concepción de María, en gracia del breve de Alexandro Séptimo que tan altamente le favorece. Y esto es, fieles, lo que oy se executa abriendo este templo, poniéndolo a la vista y a su uso sagrado" 44 .

Creemos que aquí radica la clave interpretativa del edificio, que fue entendido para sus coetáneos como una suerte de arquitectura festiva de carácter permanente. Y en ello insiste el predicador al señalar que esa era la ventaja de las fiestas celebradas en Santa María la Blanca "sobre quantas han hecho las demás iglesias de Sevilla y quizá de España también, pues de las otras entre el asombro de sus maquinadas y fingidas fábricas... acabado el día o la octava que se celebra, todo se deshaze para volverse cada adorno a su dueño". En cambio, "de aquellas puertas adentro no ha de suceder assí por que todo, en todo y por todo es fábrica real, edificio permanente, nacida, no fingida y prestada hermosura, fiesta en fin edificada, perpetua, verdadera"45.

Se pregunta el predicador “'hanse de descolgar los brocados de la capilla mayor, las granas de estas columnas, los doseles de los cielos, las telas de las paredes, ha se de descomponer aquel altar, desaliñar el retablo, trasladar de su precioso camarín el sacramento, mudar la santa imagen de su trono, desnudarla del riquísimo vestido propio de su magestad?... nada ay compuesto que descomponer, nada ageno que quitar porque nada es representado, sino todo es verdadero y el día después de acabada esta fiesta estará este templo en la misma verdad de su adorno que oy por que se obró y ha salido de suerte que no tiene ni ha menester más adorno que a sí mismo, para que el templo pueda ser, sin poner, ni quitar, la misma fiesta edificada, viva y eterna que en gloria del santo primero instante de la concepción de María en él se celebra. Todo es templo, nada más ay que templo nada ut similito templi. Y por esto es ventajosa a las demás fiestas y excelsamente maravillosa esta solemnidad en que concurren tan singulares maravillas sobre las que hubo en las antes celebradas" 46.

La anterior cita es tan expresiva y plástica que sobra cualquier comentario. En cualquier caso, el predicador da otras claves interpretativas del edificio. Así, resulta esclarecedor que diga "tengo yo (como si dixera Dios) guardado en mi escondida iglesia de Santa María la Blanca un increíble tesoro de maravillas que han de descubrirse a su tiempo, quando ya fuera de tiempo menos se espere, como no se espera la nieve por el estío". Estas maravillas tenían su función, como señala el predicador al afirmar que "las maravillas que tenía Dios atesoradas en este templo de Santa María de las Nieves que sin pensarse ya ha querido manifestar para hazer guerra al pecado original enemigo que se oponía un instante a la concepción de su madre" 47 .

\footnotetext{
${ }^{44}$ Ibid., fol. 32 .

${ }^{45}$ Ibíd., fol. 32 vto.

${ }^{46}$ Ibid., fol. 33.

${ }^{47}$ Ibid., fol. 34.
} 
Otras frases del mismo predicador evidencian la significación del edificio, como cuando alude a él como "templo pequeño, el menor de Sevilla, el minimus natu entre las parrochiales capillas del cabildo, en este sitio, como fuera de la ciudad y casi en el campo retirado, que no parece puede parecer en orden con los demás". A ello añade los calificativos de relicario precioso y agraciado y que "con singular oculto misterio descubre este blanco templo de Santa María la Blanca, en todo el bulto de su hermosura, su místico y su natural candor en que trae fundada la ventaja del mérito para ser coronado". Alude igualmente al "candor de este festivo templo"48.

También compara el trono ebúrneo de Salomón con el "trono de María en el instante primero" y con la propia iglesia de Santa María la Blanca, a la que se refiere como "este blanco trono de marfil", el cual "salió tan precioso y singular que no se ha visto fábrica semejante". Por ello arenga a los devotos: "mirad, fieles dichosos, este templo precioso, hermoso, dorado, blanco asseado, magnífico, resplandeciente, devoto que admira, entretiene, aficiona, enternece y eleva. ¿No es un cielo? cielo es y cielo verdadero por que las glorias verdaderas que haze hazen verdadero cielo al cielo, se gozan en su modo por la presencia de Iesu Christo y de su Madre en este sagrado cielo y porque tiene de la tierra quanto resplandeciente y hermoso puede hazer de la tierra cielo" ${ }^{49}$. Todo lo cual enlaza con la interpretación que hacía Maraval del barroco.

El predicador compara la iglesia y el templo de Salomón: "pretendo grangear tu benevolencia trasladando a ti, con encontrado intento, los clamores que al templo de Jerusalem encaminó en su capítulo onze Zacharias que me parece se te ajustan con no desigual propiedad". Continúa señalando que "por el monte Líbano blanquísimo, por siempre cubierto de nieves, se llamó Líbano el templo de Jerusalem, ¿por qué no has de llamarte tu relicario ilustre entre los templos de Sevilla, por qué no has de llamarte tu Libano también, blanco como la nieve en lo natural y blanquísimo por lo mystico por dedicado a Santa María la Blanca? Esto es, Santa María de las Nieves, colocada sobre monte nevado por sitial. A ti digo pues Libano hermoso que oy nos das a ver de nuevo tu esplendor y hermosura, abre de par en par tus fuertes y hermosas puertas" ${ }^{50}$. Todo lo cual enlaza con las inscripciones que leemos en los muros de la iglesia.

Son muchas las frases que podríamos espigar para entender cuáles fueron las aspiraciones que llevaron a levantar Santa María la Blanca y que hoy nos permiten entenderla. Sin duda, una de las más importantes es la comparación con el templo de Jerusalén, pero otras no por menos habituales son menos significativas, como cuando denomina a la Virgen "la triunfal carroça del hijo de

\footnotetext{
48 Ibíd., fols. $34-36$.

${ }^{49}$ Ibíd., fols. 40 vto-41.

${ }^{50}$ Ibíd., fols. 41-41 vto.
} 
Dios, victorioso de Satanás, del pecado, de la muerte, ostentando la gracia y la gloria del Redentor" 51.

Las alusiones marianas se suceden, como cuando dice "candor divino, purísimo, cristalino espejo de la eterna magestad, que vuelve su imagen, hallé escrito en el libro de la Sabiduría, que es María en su concepción: candor, speculum, imago. $Y$ si pareciere a alguno que me adelanto demasiado en apropiar a la madre estas soberanas calidades tan propias del hijo divino, naciendo en la eternidad de su padre y que esto no se debe hazer sin notoria limitación, bástele leer la con que el glorioso padre San Bernardo se las dexa apropiadas, considerándola en aquella mujer portentosa que por symbolo más célebre de la Concepción se manifestó en el Apocalipsis, vestida toda y embestida desde entonces al primero instante, del Sol de la divinidad" $"$.

Tras este primer sermón se suceden los demás de la novena y la obra termina con la "descripción panegírica de esta insigne fiesta" que lleva a cabo Torre Farfán, en la que vuelve a comparar la fiesta y el edificio al aludir a las letanías lauretanas ${ }^{53}$.

Sin duda, la iglesia de Santa María la Blanca es ejemplo evidente de la compleja y sutil relación que tuvo la arquitectura festiva y la permanente durante el barroco. En esta ocasión, esta última estuvo inspirada en la primera. Sin duda, lo más significativo es que don Justino de Neve entendió que su iglesia de Santa María la Blanca de Sevilla era una "fiesta edificada, verdadera, viva y eterna".

Fecha de recepción: 2 de septiembre de 2014

Fecha de aceptación: 28 de noviembre de 2014

${ }^{51}$ Ibid., fol. 45. Téngase en cuenta que en esos momentos empezaban a difundirse por España las "grands carrosses" francesas que se habían hecho distintivas de la corte de Luis XIV.

${ }^{52}$ Ibíd., fols. 49-50.

${ }^{53}$ Ibid., fol. 175 vto. 


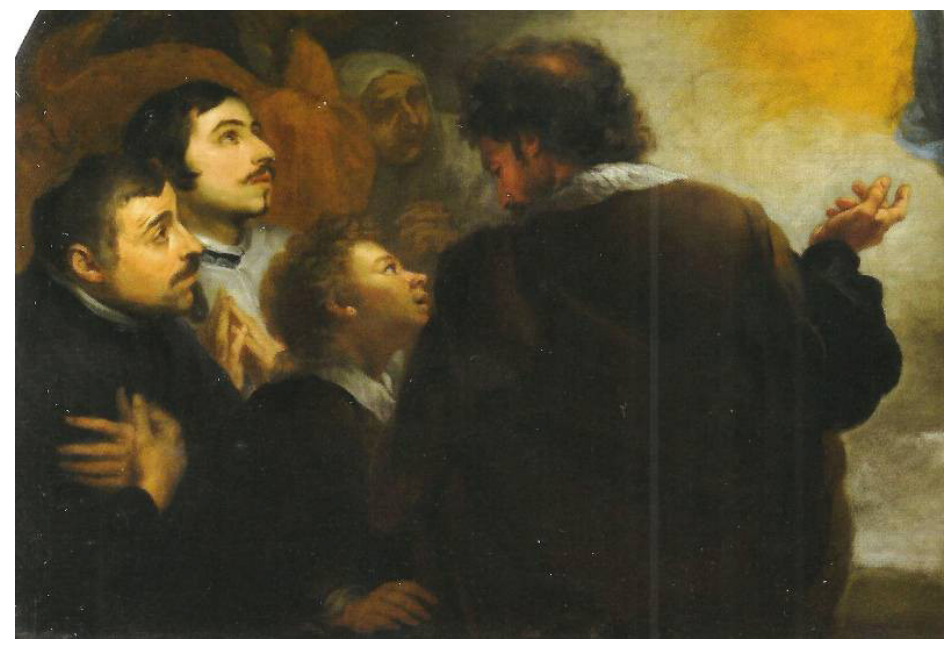

Figura 1. Inmaculada Concepción, detalle de los retratos de don Justino de Neve y de don Domingo Velázquez Soriano, Bartolomé Esteban Murillo, 1664-1665, Museo del Louvre, París.

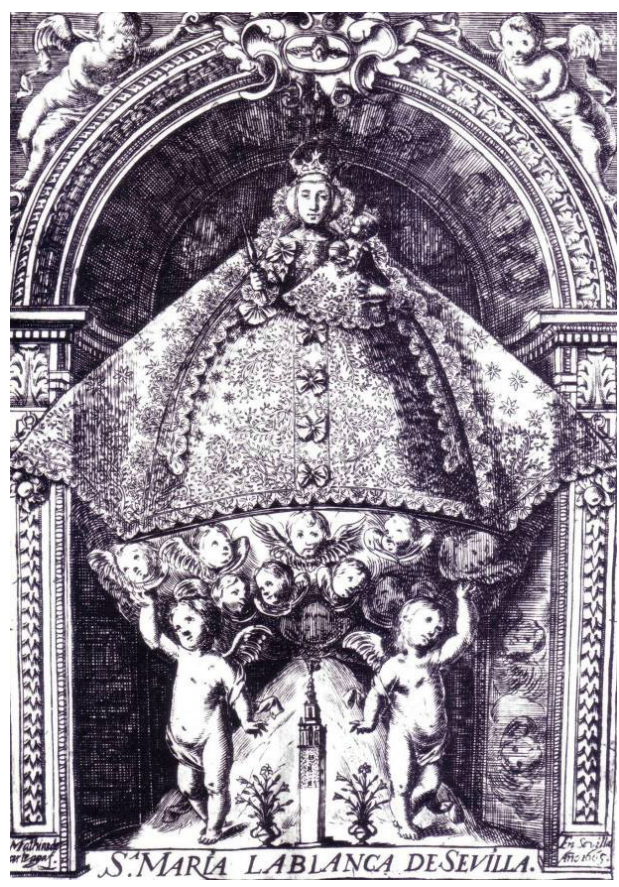

Figura. 2. Santa María la Blanca de Sevilla, Matías de Arteaga, 1665. 


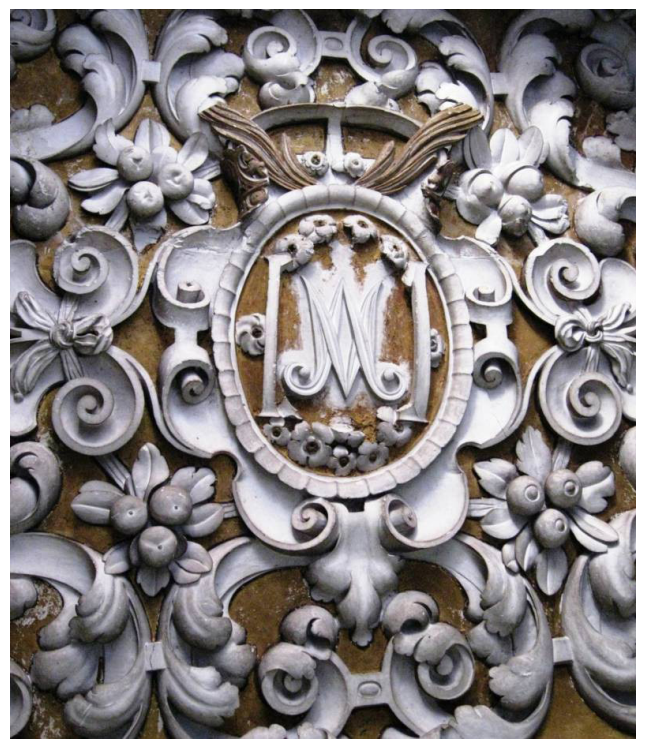

Figura. 3. Yeserías, Pedro de Borja, 1665, sotocoro de Santa María la Blanca de Sevilla.

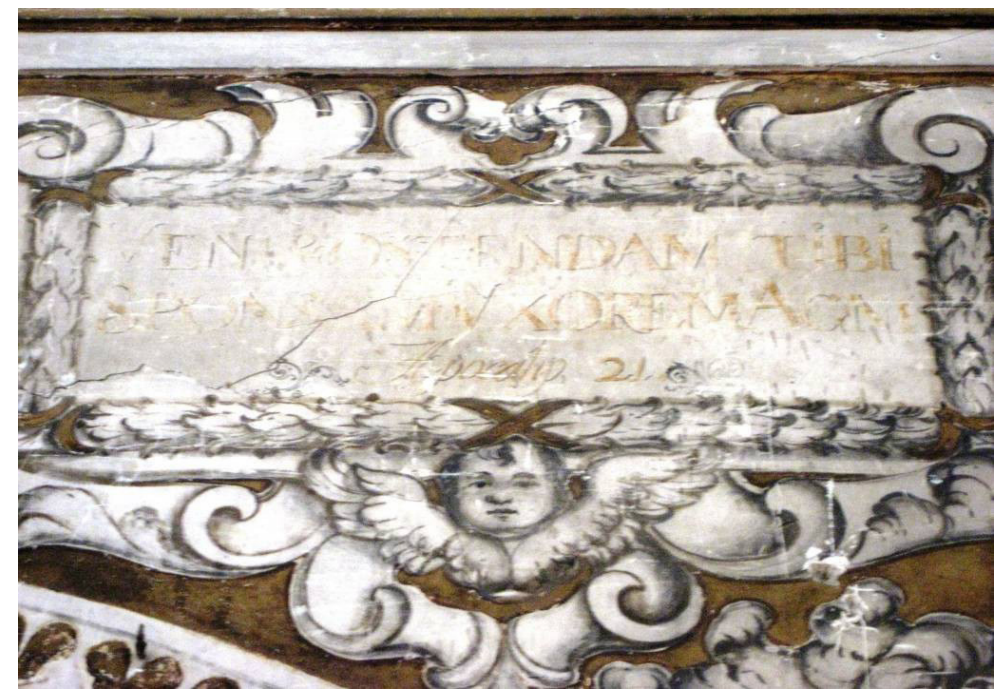

Figura 4. Inscripción, taller de Bartolomé Esteban Murillo, 1665, Santa María la Blanca de Sevilla. 


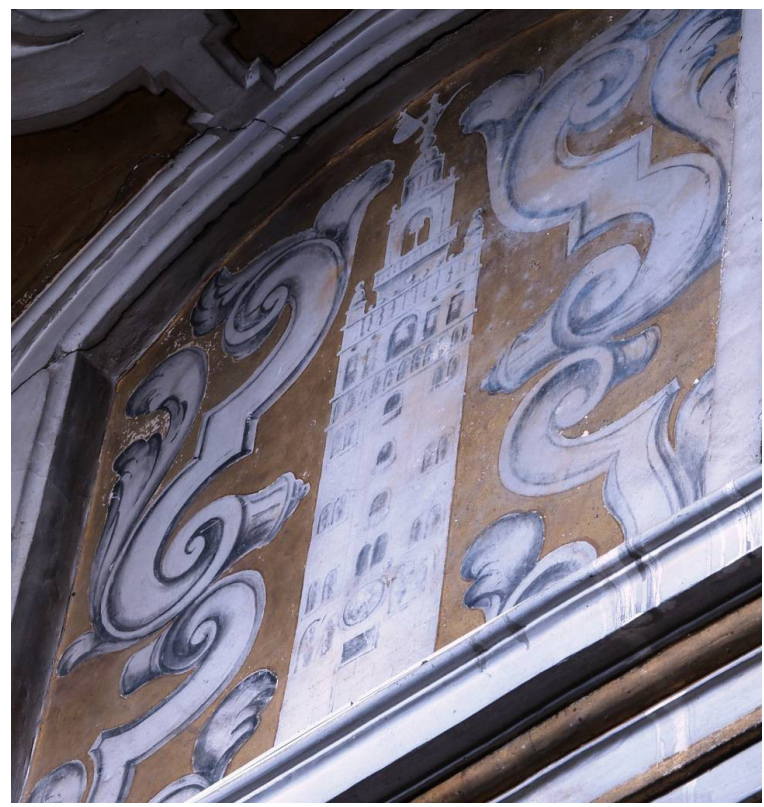

Figura 5. Giralda, taller de Bartolomé Esteban Murillo, 1665, Santa María la Blanca de Sevilla.

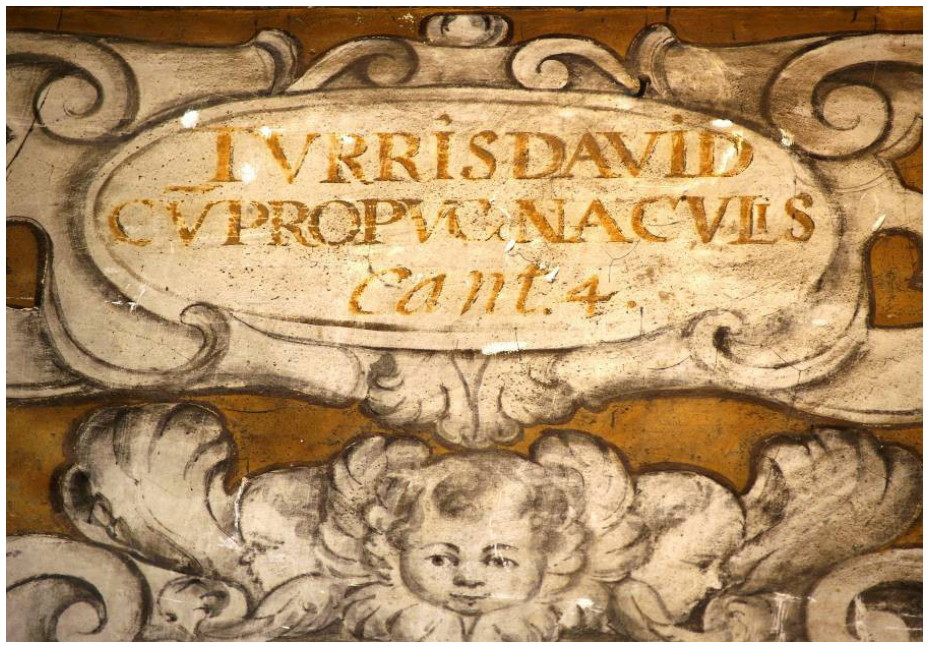

Figura 6. Inscripción, taller de Bartolomé Esteban Murillo, 1665, Santa María la Blanca de Sevilla. 


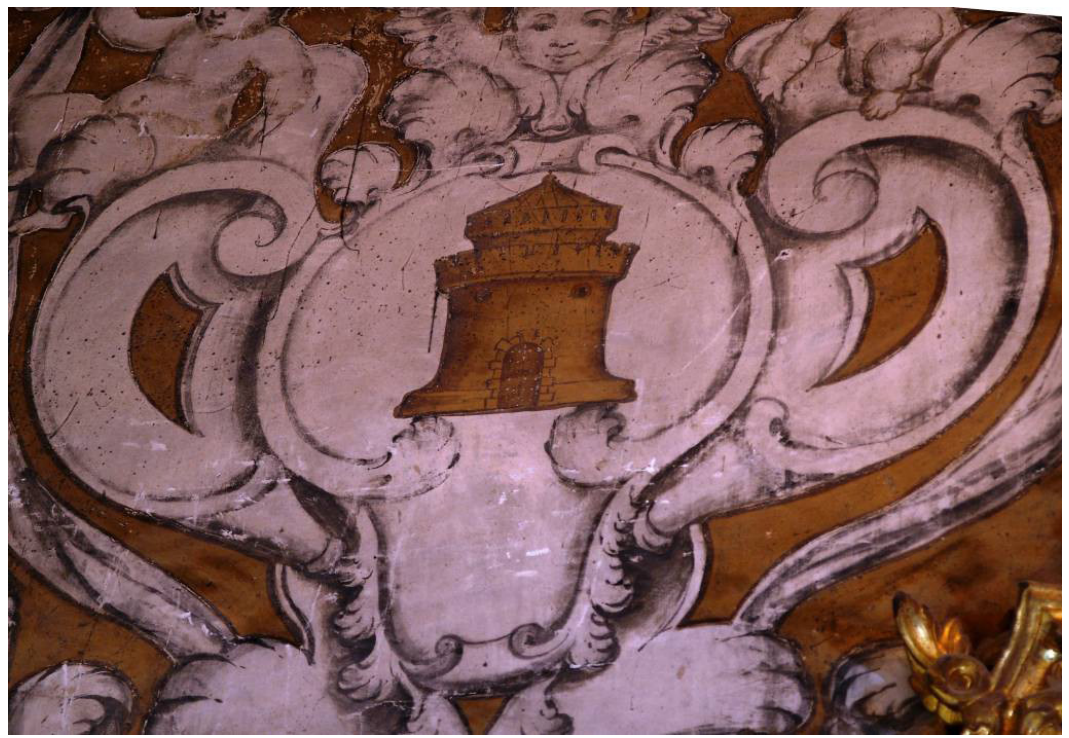

Figura 7. Emblema, taller de Bartolomé Esteban Murillo, 1665, Santa María la Blanca de Sevilla.

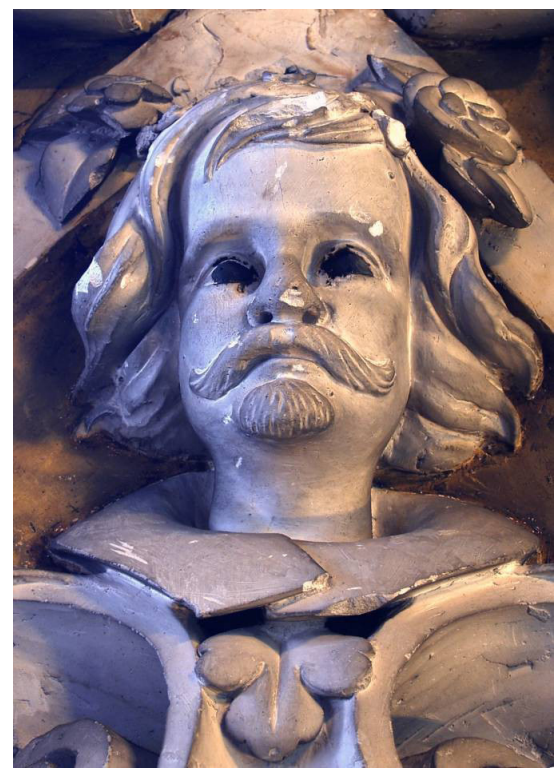

Figura 8. Felipe IV, Pedro de Borja, 1665, Santa María la Blanca de Sevilla. 


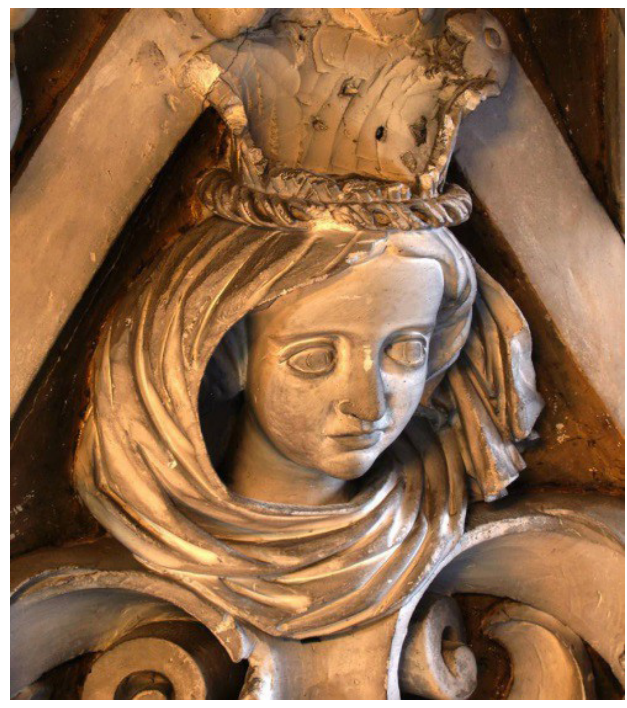

Figura 9. Mariana de Austria, Pedro de Borja, 1665, Santa María la Blanca de Sevilla.

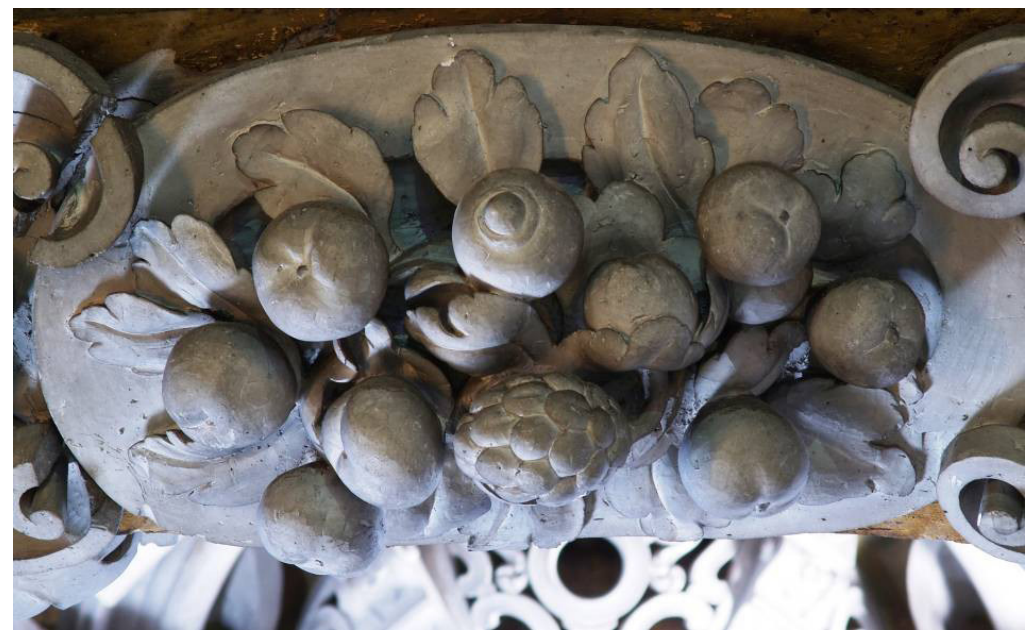

Figura 10. Bodegón, Pedro de Borja, 1665, Santa María la Blanca de Sevilla. 